\title{
Determinants of the effective tax burden of companies in the Telecommunications activities in the Republic of Croatia
}

\author{
Marijana Bubanic * \\ Hrvoje Šimović ${ }^{* *}$
}

Abstract: The aim of this paper is to identify the determinants of the effective tax burden of companies in the activity division Telecommunication in the Republic of Croatia. The research covers the time interval from 2008 to 2017. Dynamic panel analysis was used to conduct the research. Microeconomic data were obtained from the databases of the Financial Agency, and macroeconomic data from the Central Bureau of Statistics. The results indicate that the effective tax burden of companies in the activity division Telecommunication is affected by the effective tax burden from the previous period, company size, leverage, inventory intensity, profitability and economic cycle. While capital and labour intensity didn't prove statistically significant. The main limitations of the research lie in the impossibility of generalizing the stated results to all companies from the observed activity, using only one evaluation model, and being a cabinet-type research, without confirmation of the results obtained by companies. The research received several scientific contributions: this is the first study of the determinants of the effective tax burden conducted in the Republic of Croatia; the research covers an entire activity whit different companies sizes, and not as in most previous research, which mainly include only large companies listed on the stock exchange; unlike previous studies that used a balanced sample, and in most cases static panel models, this study used an unbalanced sample and a dynamic panel model.

Keywords: effective tax burden; determinants; impact; activity; Telecommunications; Republic of Croatia

JEL Classification: $\mathrm{H} 25, \mathrm{H} 29, \mathrm{H} 32$

\footnotetext{
* Marijana Bubanić is at University of Zagreb, Faculty of Organization and Informatics, Varaždin, Croatia.

** Hrvoje Šimović is at Faculty of Economics and Business, University of Zagreb, Zagreb, Croatia.
} 


\section{Introduction}

In the period from January 2001 to 31. December 2016., corporate income tax (CIT) was generally paid at the statutory rate of $20 \%$, but in 2017 it was reduced to $18 \%$ and $12 \%$, respectively ${ }^{1}$. However, a small number of companies actually pay taxes at the statutory rate. Namely, the law introduced tax incentives and reliefs that enable reduction of the corporate tax burden for many companies below the statutory tax rate.

The effect of tax reliefs is not uniform among companies. Some companies use more tax incentives than others, resulting in differences in effective tax rates among companies. While some companies pay tax at a lower effective tax rate than the statutory one, other companies may even pay tax at a higher effective rate than the statutory.

In the last few years, there has been an increase in scientific papers that investigate the impact of certain determinants on the effective tax burden of companies. However, they are mainly focused at large companies listed on the stock exchange of a particular country. The effective tax burden in the Republic of Croatia is an insufficiently researched area. According to the authors' knowledge, so far only a few authors in Croatia have dealt with this field, who have used the Devereux-Griffith model for this purpose (Šimović, 2009; Kukić, 2006; Švaljek, 2006). Bubanić \& Korent (2020) analyse the macro-effective tax rates of the Republic of Croatia and selected countries, as well as selected activities of the Republic of Croatia. Nevertheless, so far, no research has been conducted in the Republic of Croatia that would identify determinants that affect the effective tax burden of companies.

The main objective of this research is to identify the determinants of the effective tax burden of companies registered in the Republic of Croatia in the activity division Telecommunications according to the National Classification of Activities $2007^{2}$. The study of the entire activity and the inclusion of all companies from the same, allows to draw more appropriate conclusions than to consider only a small sample of companies from individual activities, and to draw conclusions on a significantly smaller set of data. The telecommunications industry is considered one of the most important segments of the development of any economy, including the Croatian one (Bubanić, 2020). Such an analysis, of only one activity important for the economy, could contribute to the preparation of a specific framework for this type of companies. This industry has a significant contribution to the Croatian economy, which can be seen from further data. According to the data of the Financial Agency from the official database info.biz, companies from the activity division Telecommunication in 2016 had a share in the total profit tax of 3.84\% of all companies in the Republic of Croatia, and in 2017 a share of 3.06\%. In 2016, companies in the Republic of Croatia recorded an average income tax in the amount of HRK 61,022, while companies in the activity division Telecommunication an average in the amount of HRK 967,111. In 2017, companies in the Republic of Croatia recorded an average corporate income 
tax in the amount of HRK 55,689, and companies in the activity division Telecommunications an average in the amount of HRK 728,079. (Financial Agency [FINA], 2021) Reduced income tax amounts were expected, given that there was also a reduction in the statutory income tax rate. Significantly higher average amounts of corporate income tax from the Telecommunications activity compared to companies from the entire territory of the Republic of Croatia, make them interesting for researching the effective tax burden.

In order to investigate the main aim of this research, i.e. to identify the determinants of the effective tax burden of companies in the activity division Telecommunications of the Republic of Croatia, it is necessary to start from the main research question: "Which determinants affect the effective tax burden of companies?". Based on the research question, and the literature review given in Chapter 2, in order to achieve the main research aim, we start from the research assumptions that the effective tax burden of companies in the activity division Telecommunication in the Republic of Croatia is affected by:
1. Company size,
2. Financial leverage,
3. Capital intensity,
4. Inventory intensity,
5. Profitability,
6. Labour intensity, and
7. Economic cycle.

\section{Literature Review of Determinants of Effective Tax Rate}

The effective (real) tax burden is measured by the effective (real) tax rate, which present a picture of the complete tax performance, and it's a measure that includes the use of tax reliefs and incentives (Harris and Feeny, 2003). This is the rate that measures the taxpayer's actual tax liability. Effective tax rate is calculated as the share of tax collected in the tax base that has not yet been adjusted to legal provisions, and so it expresses the taxpayer's actual, economic tax burden (Jelčić, 2001; Kesner-Škreb, 1997; Liu and Cao, 2007). Ott (1999) states that the effective corporate income tax liability is expressed as the tax base rate, i.e. as a tax rate that takes into account all elements of the tax system, not just the statutory tax rate. Therefore, the effective tax rate shows the actual, economic tax burden of the taxpayer. (Bubanic \& Korent, 2020)

A review of previous research has shown that they examined the relationship between the effective tax rate (indicator of the effective tax burden) and the characteristics of the company, such as: size, capital intensity, leverage, inventory intensity, profitability, labour intensity; and macroeconomic impact (economic cycle). 
In empirical research, the most common variable whose impact on the effective tax burden is sought to be proven is the company size. Siegfried (1972) studied the impact of firm size on the effective tax rate by assuming that larger firms have a less effective tax burden. This variable is included in the research for two basics but mutually opposite reasons. On the one hand, this relationship will be positive, confirming the hypothesis of political costs, where greater "visibility" of large companies exposes them to greater regulatory action. Conversely, the relationship between a firm's size and its effective tax burden is negative if larger firms have greater opportunities for tax planning and the adoption of accounting practices, which allow them to reduce the effective tax burden. The relationship can also be negative if larger companies enjoy greater political power. (Zimmerman, 1983) A review of previous research shows that in most research, the company size is a determinant of the effective tax burden. In these studies, the firm size variable has a statistically significant impact on the company's effective tax rate, whether positive or negative. A positive significant relationship was found in the research Fernandez-Rodriguez \& Martinez-Arias (2012) Fernandez-Rodriguez \& Martinez-Arias (2014), which confirms the hypothesis of political costs, i.e. that larger companies are under greater tax control. In contrast, research by Richardson \& Lanis (2007) and Savitri (2017) found a negatively significant relationship between the firm's size variable and effective tax rate. This confirms the hypothesis of tax planning and political power of large companies, i.e. larger companies invest more efforts in tax planning. But there are also studies that do not find a statistically significant impact of firm size on its effective tax burden (Liu \& Cao, 2007). Accordingly, any form of statistical significance (or insignificance) between the firm size and its effective tax burden can be expected.

The company's asset mix affects its effective tax burden. In this research, the determinants of company's asset mix that affect its effective tax burden will be the size of investments in tangible fixed assets (capital intensity), and investment in inventories (inventory intensity). Capital intensity is an important determinant that affects company's effective tax burden. Tax reliefs related to investments in fixed assets (primarily fixed tangible assets) such as accelerated depreciation rates, capital reliefs, etc., should enable companies to reduce corporate income tax liabilities, and consequently it's effective tax burden (Fernandez-Rodriguez \& Martinez-Arias, 2014) In all tax systems, depreciation (of property, plant and equipment) is deducted before tax. Therefore, companies with a higher level of tangible fixed assets (higher capital intensity) should have a lower effective tax burden. The stated negative relationship between the effective tax burden and the higher level of tangible fixed assets is confirmed by Fernandez-Rodriguez, \& Martinez-Arias (2014) and Savitri (2017), while Janssen \& Buijink (2000) deny the above. Related to the company's asset mix, an important determinant of the effective tax burden is the intensity of investment in inventories, and it should have the opposite effect on the company's effective tax burden than capital intensity. Accordingly, companies with 
higher capital intensity are expected to have a lower tax burden, so companies with higher inventory intensity should face a higher effective tax burden, as confirmed by Gupta \& Newberry (1997). Savitri (2017) in his research refutes the above, and finds a significantly positive relationship between the effective tax burden and inventory intensity.

Observing the impact of financial leverage on the effective tax burden of companies, the results of most studies suggest that this impact is statistically significant (Fernandez-Rodriguez \& Martinez-Arias, 2014; Liu \& Cao, 2007; Gubata \& Newberry, 1997), i.e. that financial leverage is a determinant of company's effective tax burden. Namely, interest expenses represent a tax deduction in profit, which leads to tax savings due to the use of external sources of funds (Dvorski, Kovšca \& Vincek, 2018). The cost of interest can be deducted from a company's pre-tax income, while dividends do not. This could mean that the capital structure of a company can affects its effective tax burden. (Liu \& Cao, 2007) The results of empirical research indicate that financial leverage significantly negatively affects company's effective tax burden (Janssen \& Buijink, 2000; Liu \& Cao, 2007), which is expected, because interests are deductible from pre-tax income. Which means that companies with a higher level of indebtedness have a lower effective tax burden.

One of the determinants of company's effective tax burden is profitability. The most profitable companies make higher profits and pay corporate income tax (almost) every year. Conversely, less profitable companies make lower earnings, or even losses, and thus pay a lower amount of corporate income tax, or do not pay it at all. Given that permanent and temporary accounting differences affect the company's profitability, using carried forward losses (type of temporary difference), companies can reduce their tax liabilities for the coming business years. Evidence from empirical research suggests a significantly positive association between profitability and companies effective tax burden (Liu \& Cao, 2007; Rodriguez \& Martinez-Arias, 2014). Savitri (2017) finds the opposite results, i.e. confirms the negatively significant impact of profitability on company's effective tax burden.

Labour intensity is rarely investigated determinant in studies of the effective tax burden. The burden of employee social security falls on the company's cost, thereby reducing their profitability and consequently effective tax burden (Ooghe, Schokkaert \& Flechet. 2003; Wilkie, 1988; Lazar, 2014). Spengel, Li, Finke \& Zinn. (2011) argues that the inclusion of labour costs in production costs delays their deductibility, because they become an expense when the products are sold, which increases the profit tax. Consequently, there is a possibility that the labour intensity variable also affects company's effective tax burden. Gubata \& Newberry (1997) include the labour intensity determinant in their research, however, no statistically significant impact of this determinant on the effective tax burden has been proven. Notwithstanding, in order to satisfy the research curiosity, this determinant will be included in the subject research. 
All the mentioned determinants are internal, specific to each company. However, the company's effective tax burden is also subject to possible macroeconomic influences, such as the economic cycle. Rodriguez \& Arias (2012) include the economic cycle in the research as a control variable, and measure the same using the growth rate of gross domestic product (GDP).

For previously selected determinants, empirical research yield opposites result in terms of significance, and positive or negative impact on the company's effective tax burden.

\section{Sample design, Model Specifications and Variable Definitions}

\section{Sample design}

This research covers all companies registered in the database of the Financial Agency in the period from 2008 and 2017 registered in activity division J61 Telecommunications according to the National Classification of Activities (2007). The analysis includes all companies that submitted basic financial statements for the reference year. Activity division J61 Telecommunications comprises four classes: J6110 Wired telecommunications activities, J6120 Wireless telecommunications activities, J6130 Satellite telecommunications activities, and J6190 Other telecommunications activities. Previous research examining the issue of the effective tax burden has mainly considered listed companies, while research examining a separate whole activity almost don't exist ${ }^{3}$.

Table 1 shows the distribution of the number of companies in activity division J61 Telecommunications used in the study. Central tendency measures indicate an increase in the number of companies over the years. In the distribution of the number of companies in activity division J61 Telecommunications, the largest share has companies from the class J6110 Wired Telecommunications activities. In 2008, this share was $60.83 \%$ and in 2017 the share was $47.33 \%$. While the share of these companies is decreasing, the share of companies from the class J6190 Other telecommunications activities is increasing. In 2008 the share was $16.13 \%$, and in 2017 it was $24.14 \%$. 
Table 1: Distribution of the number of companies in activity division J61 Telecommunications

\begin{tabular}{|c|c|c|c|c|c|c|c|}
\hline \multirow[b]{2}{*}{ Year } & \multicolumn{4}{|c|}{ Classes of the activity division J61 Telecommunication } & \multirow[b]{2}{*}{ Sum } & \multirow[b]{2}{*}{ Mean } & \multirow[b]{2}{*}{ Median } \\
\hline & $\begin{array}{c}\text { J6110 } \\
\text { Wired* }\end{array}$ & $\begin{array}{c}\text { J6120 } \\
\text { Wireless* }\end{array}$ & $\begin{array}{c}\text { J6130 } \\
\text { Satellite* }\end{array}$ & $\begin{array}{c}\text { J6190 } \\
\text { Other* }\end{array}$ & & & \\
\hline 2008 & 132 & 44 & 6 & 35 & 217 & 54,25 & 39,5 \\
\hline 2009 & 154 & 43 & 4 & 20 & 221 & 55,25 & 31,5 \\
\hline 2010 & 136 & 51 & 7 & 51 & 245 & 61,25 & 51 \\
\hline 2011 & 143 & 50 & 7 & 59 & 259 & 64,75 & 54,5 \\
\hline 2012 & 147 & 42 & 7 & 64 & 260 & 65 & 53 \\
\hline 2013 & 151 & 47 & 8 & 75 & 281 & 70,25 & 61 \\
\hline 2014 & 151 & 51 & 7 & 83 & 292 & 73 & 67 \\
\hline 2015 & 146 & 53 & 7 & 92 & 298 & 74,5 & 72,5 \\
\hline 2016 & 141 & 55 & 7 & 90 & 293 & 73,25 & 72,5 \\
\hline 2017 & 142 & 56 & 8 & 94 & 300 & 75 & 75 \\
\hline Sum & 1443 & 492 & 68 & 663 & 2666 & 666,5 & 577,5 \\
\hline Mean & 144,3 & 49,2 & 6,8 & 66,3 & 266,6 & & \\
\hline Median & 144,5 & 50,5 & 7 & 69,5 & 270,5 & & \\
\hline
\end{tabular}

*telecommunications activities

Source: Authors' systematization according to Financial agency data

Table 2 shows the distribution of companies from the sample by size ${ }^{4}$. So far, large companies have been mainly included in the studies (Fernandez-Rodriguez \& Martinez-Arias, 2012). The subject research includes companies of all sizes, with micro and small companies predominating.

Table 2: Distribution of the number of companies by size

\begin{tabular}{|l|c|c|c|c|c|c|c|c|c|c|}
\hline \multirow{2}{*}{ Size } & \multicolumn{10}{|c|}{ Year } \\
\cline { 2 - 12 } & $\mathbf{2 0 0 8}$ & $\mathbf{2 0 0 9}$ & $\mathbf{2 0 1 0}$ & $\mathbf{2 0 1 1}$ & $\mathbf{2 0 1 2}$ & $\mathbf{2 0 1 3}$ & $\mathbf{2 0 1 4}$ & $\mathbf{2 0 1 5}$ & $\mathbf{2 0 1 6}$ & $\mathbf{2 0 1 7}$ \\
\hline Micro & & & & & & & & & 251 & 263 \\
\hline Small & 207 & 210 & 234 & 248 & 248 & 269 & 279 & 285 & 29 & 25 \\
\hline Medium & 5 & 4 & 5 & 5 & 4 & 5 & 7 & 6 & 7 & 6 \\
\hline Large & 5 & 7 & 6 & 6 & 8 & 7 & 6 & 7 & 6 & 6 \\
\hline
\end{tabular}

Source: Authors' systematization according to Financial agency data

Similar studies typically use a balanced sample (Fernandez-Rodriguez \& Martinez-Arias, 2012; Liu \& Cao, 2007) which means that only companies that persist throughout the observed period are included in the research, thus omitting companies that entered and left activities during the observed period. In this research, an 
unbalanced sample will be used, i.e. all companies that found themselves in the reference year will be included in the study, including companies that entered and left the activity division in the observed period. Involving all companies in research and using an unbalanced sample gives a scientific contribution. Following the example of previous research, only non-financial companies were included in this research.

\section{Model specification}

In order to conduct research, in addition to the methods of descriptive statistics, a panel regression analysis will be used, i.e. a method that simultaneously uses the advantages of time series methods and cross-section methods. In this kind of studies, static panel models are mostly used (Fernandez-Rodriguez \& Martinez-Arias, 2012), while dynamic panel models are rarely represented (Fernandez-Rodriguez \& Martinez-Arias, 2014). This study used a GMM dynamic panel model with Arellano-Bover / Blundell-Bond estimator, whose popularity is growing in the scientific community (Arellano \& Bover 1995; Blundell \& Bond 1998; Roodman, 2009).

The application of this estimator is appropriate because it takes full advantage of the Arellano-Bover estimator - (1) when the study takes into account several time periods (small T) and many companies (large N), as in this case; (2) when estimating linear relationships; (3) when the dependent variable is dynamic, i.e. it depends on its own past movements (in this study, this would include the need to use the lagged dependent variable to capture the dynamic nature of the effective tax burden variable); (4) the likely endogeneity of the independent variables; (5) individual fixed effects; (6) heteroskedasticity and autocorrelation within, but not between, observations (companies); - and makes an additional assumption (7) that the first differences of the instrument variables are not correlated with fixed effects. (Roodman, 2009) An additional assumption allows to introduce more instruments and improves efficiency.

In order to test the assumptions, i.e. the significance of the impact of individual determinants on the company's effective tax burden, the following model is assessed:

$$
\begin{aligned}
& \text { Effective tax } \text { burden }_{i t} \\
& =\beta_{0}+\beta_{1} \text { effective tax } \text { burden }_{i t-1}+\beta_{2} \text { size }_{i t}+\beta_{3} \text { financial leverage }_{i t} \\
& +\beta_{4} \text { capital intensity }_{i t}+\beta_{5} \text { inventory intensity }_{i t}+\beta_{6} \text { asset profitability }_{i t} \\
& +\beta_{7} \text { capital profitability }_{i t}+\beta_{8} \text { labor intensity }_{i t}+\text { economic cycle }_{t}+\varepsilon_{i t}
\end{aligned}
$$

or abbreviated form:

$$
\begin{aligned}
E T R_{i t}= & \beta_{0}+\beta_{1} E T R_{i t-1}+\beta_{2} \operatorname{SIZE}_{i t}+\beta_{3} L E V_{i t}+\beta_{4} C A P I N T_{i t}+\beta_{5}{I N V I N T_{i t}} \\
& +\beta_{6} R O A_{i t}+\beta_{7} R O E_{i t}+\beta_{8} L A B I N T_{i t}+G D P_{t}+\varepsilon_{i t}
\end{aligned}
$$


where the symbol $i$ denotes the companies, the symbol $t$ year, $\beta_{0}$ represents the companies-specific constant that accumulates unobserved heterogeneity, i.e. time-invariant unobserved individual effects specific to a particular company $i$, and $\varepsilon_{i t}$ symbolizes an error.

\section{Data and variables used}

In the analysis, data from the Financial Agency were used. The data include registered companies in the Republic of Croatia whose predominant activity according to the National Classification of Activities 2007 is the activity division J61 Telecommunications. The time period includes data from 2008 to 2017, and the data set includes only companies that have submitted financial statements for the reference year.

To calculate the variable indicators, data from the basic financial statements (balance sheet and income statement) submitted by companies to Financial Agency are used, which include: income tax, total assets (assets), short-term and long-term liabilities, tangible assets, inventories, total income, total expenses, profit before tax, net profit, capital and reserves, labour expenses. To calculate the indicators of the macroeconomic impact variable, data on the growth rate of real GDP is used, available from the Central Bureau of Statistics (Croatian Bureau of Statistics [CBS], 2020).

Data are processed using MS Excel and STATA software packages. The method of descriptive statistics is used and the obtained results are presented graphically and tabularly. In order to interpret certain results, measures of central tendency are used.

The effective tax burden variable is measured by the indicator of the effective tax rate (ETR). It represents the dependent variable in the model. There are different definitions of the effective tax rate (see for example Callihan, 1994). In this research, the effective tax rate represents the ratio of the amount of company's corporate income tax and his profit before tax, i.e.

$$
E T R=\frac{\text { Corporate income tax }}{\text { Profit before tax }}
$$

It is unrealistic to assume, that every company has achieved a positive financial result in all years, i.e. the obligation to pay corporate income tax every year. Because companies make losses in some years and profits in others, this research is conducive to using an unbalanced sample. In similar studies, it is common to exclude from the research companies that made a pre-tax loss in a given year or reported a negative income tax expense. They are excluded for two reasons: first, it is problematic to interpret a negative effective tax rate, and second, the complete exclusion of such firms allows a balanced sample (Liu \& Cao, 2007; Zimmerman, 1983). In this study, companies will not be excluded entirely, but only the data on the effective tax rate from a particular year when it is negative or shows a distorted result (for example, when 
income tax is negative and when gross profit is negative, because then the effective tax rate is positive, which does not reflect the actual situation ${ }^{5}$ ).

The first independent variable in the model is the effective tax burden from the previous period $\left(\mathrm{ETR}_{\mathrm{t}-1}\right)$ (i.e. the first lag of the dependent variable effective tax burden measure with the effective tax rate). The use of a lagged dependent variable is specific to the dynamic model, and it seeks to identify the possibility of the existence of a time adjustment of the dependent variable, i.e. ETR. Fernandez-Rodriguez, \& Martinez-Arias (2014) state that a statistically significant coefficient means that adjustments to the effective tax rate are relevant.

Firm size (SIZE) was measured as the logarithm of total assets (Fernandez-Rodriguez, \& Martinez-Arias, 2014). It was previously pointed out, that in the case of a positive correlation between the effective tax rate and the size of the company, the theory of political costs would be confirmed - larger companies will pay more taxes due to greater tax control. A negative correlation would confirm the fact that, larger companies may reduce the effective tax burden by investing in tax planning.

Financial leverage (LEV) is a possible determinant of the effective tax burden, and is measured as the debt ratio, i.e. the ratio of total liabilities to total assets (Feeny et. Al., 2006). Traditionally, a negative relationship between indebtedness and the dependent variable is expected, as interest on debt creates a tax shield, resulting in a reduction in the effective tax burden for firms with higher leverage. In the case of a positive relationship, this would mean that companies with a high tax burden (high effective tax rate) will be more motivated for borrowing.

The following two determinants are included in the research as determinants of asset structure. Capital intensity (CAPINT) is measured by the ratio of a company's tangible assets to total assets. The associated variable, inventory intensity (INVINT) is measured as the ratio of inventories to total companies' assets. Given the tax incentives associated with investments in fixed assets (such as accelerated depreciation), companies should be able to reduce their income tax liability, and consequent the effective tax rate. If the capital intensity doesn't prove to be significant, a significant impact of the inventory intensity determinant is expected, and vice versa.

Profitability can affect the company's effective tax burden. Two profitability measures will be used in this study: return on assets (ROA) and return on equity (ROE). In both measures, the net principle is used, the profitability of assets is measured as the ratio of profit after tax and total assets, and the profitability of capital as profit after tax and capital and reserves. Given the inconsistent results of previous studies, a statistically significant impact is expected, but no positive or negative relationship is predicted.

Labour intensity has rarely been investigated as a determinant of company's effective tax burden. In this study, it is measured as the ratio of labour costs to total income (Lazăr, 2014). Since in previous studies (Gubata \& Newberry, 1997; Lazăr, 2014) this determinant didn't prove as statistically significant, a similar outcome is 
expected here as well. Regardless of expectations, for the purpose of further research, it should be assessed here as well.

The macroeconomic impact (economic cycle) is measured by the growth rate of real GDP. A positive relationship between the real GDP growth rate and the effective tax rate would indicate that during the expansion, companies make higher profits and pay more taxes. Conversely, the negative impact would point to the fact that companies in the expansion phase record higher amounts of depreciation and provisions to help them overcome the recession.

The following Table 3 gives the variables, the indicators of the variables, and their measurements.

Table 3: Description of research variables

\begin{tabular}{|c|c|c|}
\hline Variable & Variable indicator & Indicator measure \\
\hline \multicolumn{3}{|c|}{ Dependent variable } \\
\hline Effective tax burden & Effective tax rate (ETR) & Corporate income tax / Profit before tax \\
\hline \multicolumn{3}{|c|}{ Independent variables } \\
\hline Firm size & Size (SIZE) & Logarithm of total assets \\
\hline Financial leverage & Indebtedness ratio (LEV) & Total liabilities / Total assets \\
\hline Capital intensity & Capital intensity (CAPINT) & Tangible assets / Total assets \\
\hline Inventory intensity & Inventory intensity (INVINT) & Inventories / Total assets \\
\hline \multirow{2}{*}{ Profitability } & Net return on assets (ROA) & Profit after tax / Total assets \\
\hline & Net return on equity (ROE) & Profit after tax / Capital and reserves \\
\hline Labour intensity & Labour intensity (LABINT) & Labour costs / Total income \\
\hline Macroeconomic impact & Real BDP & Real GDP growth rate \\
\hline
\end{tabular}

Source: Authors' work

\section{Results, discussion and limitations}

\section{Descriptive Statistics Results}

Before presenting the regression results, the following Table 4 and Figure 1 show the average and median values of the effective tax rate of the observed period, and they are compared with the statutory rate of corporate income tax. 
Table 4: Average and median effective and statutory tax rates

\begin{tabular}{|l|c|c|c|c|c|c|c|c|c|c|}
\hline \multirow{2}{*}{ ETR } & \multicolumn{10}{|c|}{ Year } \\
\cline { 2 - 12 } & $\mathbf{2 0 0 8}$ & $\mathbf{2 0 0 9}$ & $\mathbf{2 0 1 0}$ & $\mathbf{2 0 1 1}$ & $\mathbf{2 0 1 2}$ & $\mathbf{2 0 1 3}$ & $\mathbf{2 0 1 4}$ & $\mathbf{2 0 1 5}$ & $\mathbf{2 0 1 6}$ & $\mathbf{2 0 1 7}$ \\
\hline Mean ETR & 16,10 & 21,15 & 12,69 & 12,80 & 28,41 & 13,70 & $13,99^{6}$ & 16,89 & 14,94 & 10,19 \\
\hline Median ETR & 19,96 & 19,84 & $0,00^{7}$ & 5,25 & 13,53 & 11,59 & 19,86 & 18,83 & 20,00 & 12,00 \\
\hline STR & 20 & 20 & 20 & 20 & 20 & 20 & 20 & 20 & 20 & $18^{*}$ \\
\hline
\end{tabular}

* The statutory corporate income tax rate of $18 \%$ is the highest marginal rate, in 2017 two rates were used: $12 \%$ and $18 \%$.

Source: author's calculation

Figure 1: Effective and statutory tax rate

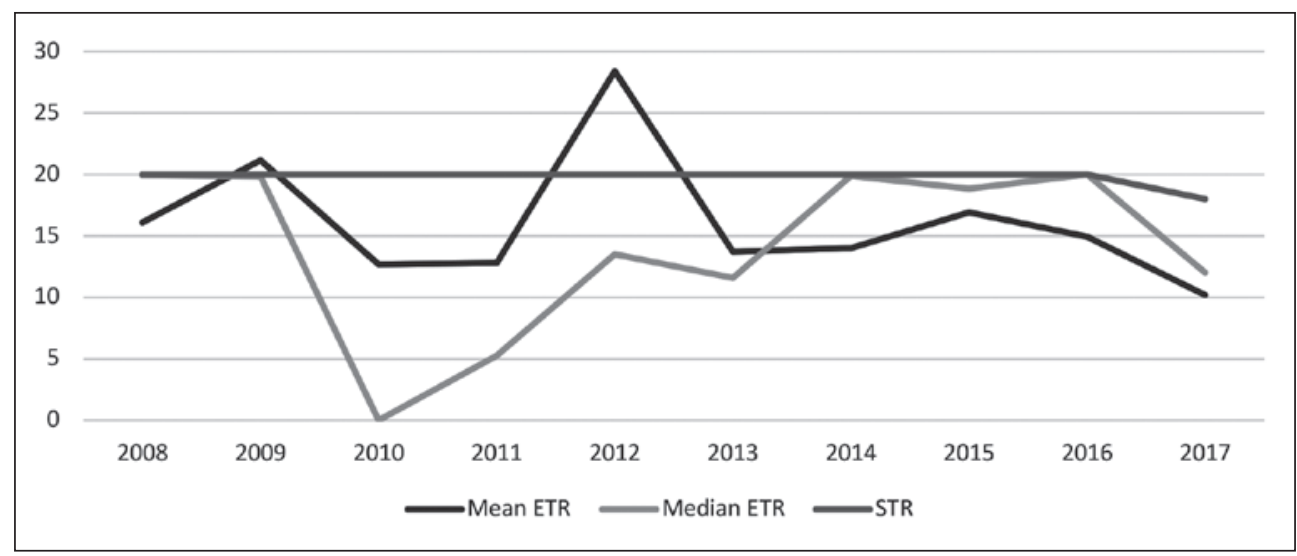

Source: Authors' work

The results show that, on average, companies pay effective corporate income tax at a lower rate than the statutory rate of corporate income tax. Exceptions of this are the years 2009 and 2012. The medial values of the effective tax rate show that half of the companies certainly pay corporate income tax at a rate lower than the statutory rate. Also, it is interesting to note that in 2017, both average and median effective tax rates declined after the statutory tax rate was reduced. The median effective tax rate in 2017 is $12 \%$, and it shows that half of companies in the activity division telecommunication pay effective corporate income tax at a rate equal to or less than the lower statutory tax rate.

The following Table 5 shows the descriptive statistics for all variables used in the study. The results of the descriptive statistics show that the average value of the effective tax rate is higher than the statutory rate of corporate income tax. The standard deviation, and the minimum and maximum values of the effective tax rate indicate high variability. The maximum value of $24,658.72 \%$ is the already mentioned outlier that appeared in 2014. The values of the firm`s size variable confirm that companies 
of all sizes, from micro to large, were included in the research. The variability of the used variables, is the result of the heterogeneity of the companies within the observed activity.

Table 5: Descriptive statistics of research variables

\begin{tabular}{|l|c|c|c|c|c|}
\hline Variable & Obs & Mean & Std. Dev. & Min & Max \\
\hline ETR & 2594 & 15,917 & 81,54299 & 0 & 3711,644 \\
\hline SIZE & 2664 & 5,649867 & 1,174253 & 0 & 10,15853 \\
\hline LEV & 2664 & $574.294,5$ & $2,49 \mathrm{E}+07$ & 0 & $1,27 \mathrm{E}+09$ \\
\hline CAINT & 2664 & 21,22649 & 27,32878 & 0 & 100 \\
\hline INVINT & 2664 & 5,10854 & 12,98393 & 0 & 96,9633 \\
\hline ROA & 2664 & $-326.851,3$ & $1,73 \mathrm{E}+07$ & $-8,92 \mathrm{E}+08$ & $4,30 \mathrm{E}+07$ \\
\hline ROE & 2556 & $16.784,81$ & 851089,9 & $-85447,82$ & $4,30 \mathrm{E}+07$ \\
\hline LABINT & 2528 & $1.605,676$ & 35938,81 & 0 & 1435596 \\
\hline GDP & 2666 & $-0,259227$ & 2,47411 & $-6,2$ & 2,9 \\
\hline
\end{tabular}

Source: author's calculation

\section{Regression Results}

The following Table 6 shows the results of the panel regression analysis.

The coefficient of the lagged dependent variable (i.e., the effective tax burden from the previous period, ETRt-1) is statistically significant. This confirms that the tax burden of one period depends on the tax burden of the previous period. This justifies the use of a dynamic panel model over static models, which don't take into account lagged dependent variables. The results are consistent with a study by Fernández-Rodríguez \& Martínez-Arias (2014) that confirmed the statistical significance of the lagged dependent variable in Brazil, Russia India, and China (BRIC). The negative sign of the lagged dependent variable's coefficient, indicates that the tax burden from one period negatively affects the tax burden of the next period. Which would indicate that companies are striving to reduce the effective tax burden from year to year. 
Table 6. Results of panel regression analysis

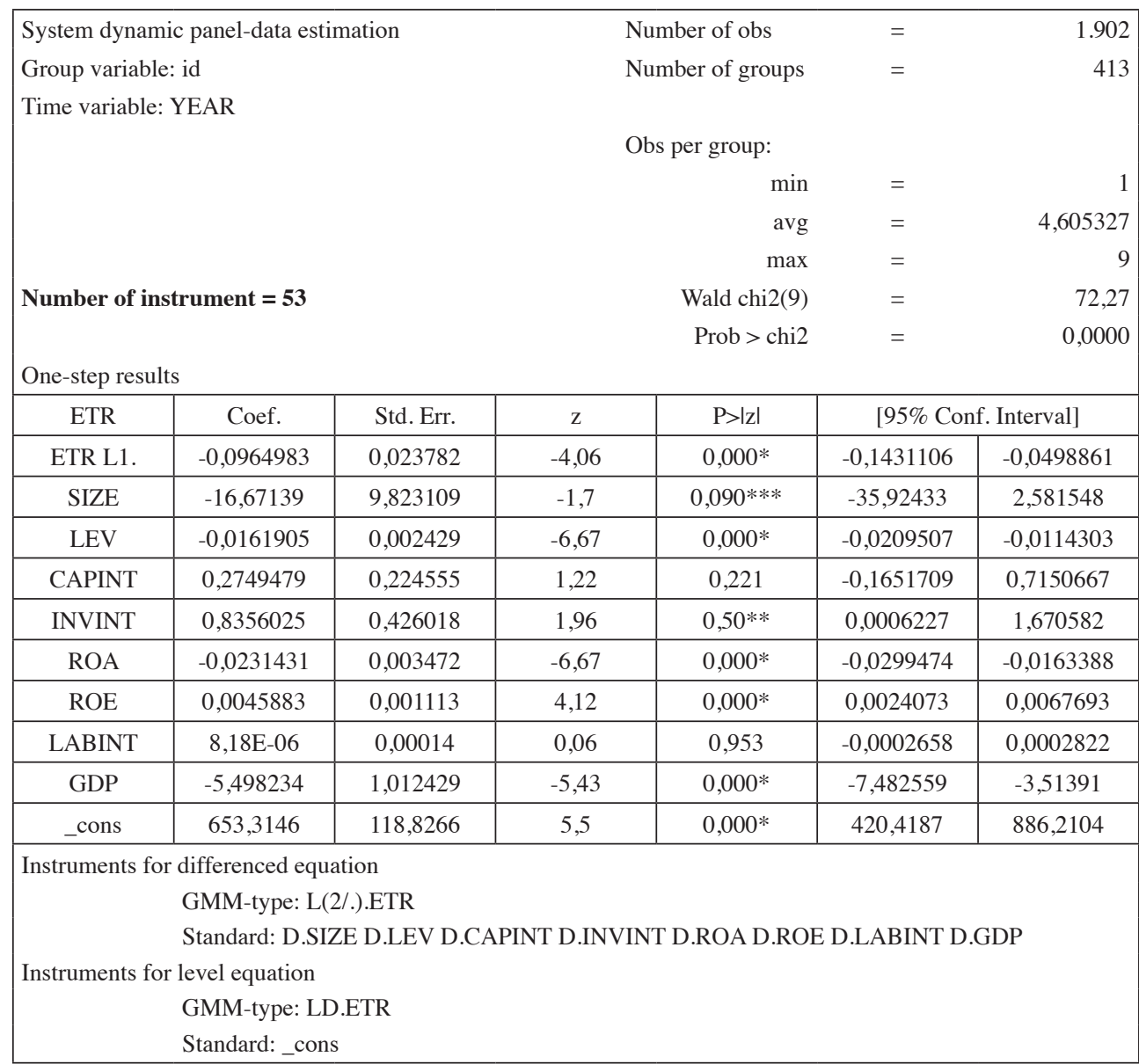

Notes: *,**,***significant at the 1,5 and 10 percent level,

Source: author's calculation

The firm size variable is statistically significant with a negative sign, suggesting that larger companies invest more in tax planning, leading to a lower tax burden. The result is consistent with research by Harris \& Feeny (2003) conducted in Australia. This confirms the research assumption that the firm size affects company's effective tax burden.

The second assumption that a firm's financial leverage affects the company's effective tax burden is also accepted. A statistically significant negative sign indicates that financial interest expenses reduce companies tax burden (the inverse effect of leverage on the effective tax burden). The results are consistent with research obtained in Russia and Brazil (Fernández-Rodríguez \& Martínez-Arias, 2014). 
The variables of capital and inventory intensity are unlikely to be significant at the same time, i.e. either a capital intensity variable or a inventory intensity variable will be significant. The results reject the third assumption about the significance of capital intensity, but the fourth assumption is accepted, that the inventory intensity significantly positively affects company's effective tax burden. Companies from the activity division Telecommunications in the Republic of Croatia with a higher inventory intensity have a higher effective tax burden. The results are consistent with research by Fernandez-Rodriguez \& Martinez-Arias (2012) who find a positively significant impact of inventory intensity on the effective tax burden.

In the research, profitability is measured with two indicators, net return on assets and net return on capital. Both profitability indicators show a statistically significant impact on the effective tax rate, but in the opposite direction, thus accepting the fifth assumption. Return on assets has a positive effect on the effective tax rate, which leads to the conclusion that companies with higher profitability of assets also have a higher effective tax rate. The results are consistent with Liu \& Cao (2007), and they state that companies with higher profitability pay effectively more taxes. Return on capital variable has a statistically significant inverse effect on the effective tax rate, implying that higher return on capital leads to a lower effective tax burden. There are few studies that have used capital profitability as a determinant of the effective tax burden. Vintilă, Gherghina, \& Păunescu (2018) use the same variable, and their results are not consistent with this study, as they also showed a positively significant impact of this variable on the effective tax burden.

The labour intensity variable did not prove to be statistically significant, thus rejecting the sixth assumption, which is contrary to the Liu \& Cao (2007) study, where it was negatively statistically significant, but according to Gubat \& Newberry (1997), which also did not find a statistically significant impact of the labour intensity variable on the effective tax burden.

The macroeconomic impact, measured by the real GDP growth rate, confirms that the economic cycle has a statistically significant effect on the effective tax burden rate. But Fernandez-Rodriguez \& Martinez-Arias (2012) didn't confirm this. Their research used a non-deflated GDP growth rate, while in this research a real GDP growth rate was used, which could explain the differences in the result. The negative coefficient of the real GDP growth variable, implies that companies from the activity division Telecommunication, in expansion phase record higher amounts of depreciation and provisions, which consequently leads to a reduction in the amount of corporate income tax and effective tax rates.

\section{Limitations}

The main limitation of the research is in the generalization of the obtained results. It is not realistic to assume that the results are valid for all analysed companies from 
the sample. Another limitation is the use of only one estimation model. Since this is a cabinet-type study, the conclusions should be confirmed by field research. Furthermore, only one indicator was used for individual variables. For future research, it is recommended to eliminate these shortcomings, using several different regression models and different variable indicators, and a combination of cabinet and field research. It is recommended to compare the results of activity division Telecommunication with the results of the effective tax burden of other activities and with national effective tax rate.

\section{Conclusions}

There are several reasons for conducting this research: first, so far, no research has been conducted in the Republic of Croatia of the determinants of the effective tax burden, secondly, similar studies generally do not cover entire activities, but listed companies, and related to this, the third reason stems from the fact that previous studies cover mainly large companies. Also, there are few studies that have used the dynamic panel method.

The research was conducted on a sample of companies in the activity division Telecommunications from the Republic of Croatia for the period from 2008 to 2017. The results show that companies from the observed activity division in most of the observed period, on average, pay corporate income tax at an effective tax rate lower than the statutory.

In the study, dynamic panel regression analysis with GMM Arellano-Bover / Blundell-Bond estimator was used. The results of applying this method, confirm that the determinants of the effective tax burden of companies from the activity division Telecommunication in the Republic of Croatia are as follows: effective tax burden from the previous period, firm size, leverage, inventory intensity, profitability and business cycle. Which accepts the first, second, fourth and sixth research assumptions.

The variable firm size is statistically significant, assuming that larger companies invest more in tax planning and thus reduce the tax effective burden. Companies from the observed activity division with a higher financial leverage have a less effective tax burden, as well as those with a higher inventory intensity. A higher level of asset profitability indicates a higher corporate income tax burden. In the expansion phase, companies in the activity division Telecommunication accounting more depreciation expenses, thus reducing the effective tax burden. 


\section{NOTES}

${ }^{1}$ Note that the $20 \%$ corporate income tax rate was valid until the end of 2016. In 2017, the tax reform included a reduction in the corporate income tax rate, so that companies with revenues of up to 3 million Croatian kuna in 2017 paid corporate income tax at a rate of $12 \%$, while companies with revenues of more than 3 million Croatian kuna paid corporate income tax at the rate of $18 \%$.

2 The activity of Telecommunications in this research is included in one of the 88 sections of the National Classification of Activities 2007, i.e. section J61 of Telecommunications.

${ }^{3}$ A study of the determinants of the effective tax rate of tourism was done by Moreno-Rojas, González-Rodríguez \& Martín-Samper (2017). But not all companies in the sector were taken into account, only hotels and travel agencies.

${ }^{4}$ Entrepreneurs are classified according to the Accounting Act. Note that until 2015, entrepreneurs were classified into small, medium and large enterprises according to the Accounting Act (NN 109/2007), and from 2016 into micro, small, medium and large enterprises according to the new provisions of the Accounting Act (NN 78/2007). / 2015).

${ }^{5}$ If the corporate income tax is zero and the company makes a profit / loss, then the effective tax rate of this company is zero, and such data are not excluded from this analysis, because it's not a distorted result $(\mathrm{ETR}=0)$.

${ }^{6}$ In 2014 , one outlier was excluded from the analysis. In the given year, this company reported a corporate income tax of HRK 1,494,072 and gross profit of HRK 6,059 (ETR $=24,658.72 \%)$. If this outlier isn't excluded from the analysis, then the average ETR is $99.56 \%$ and the median is $19.89 \%$. The ETR of this outlier in 2014 was also eliminated from the panel analysis.

7 The median value shows that half of the companies had an effective tax rate equal to zero. In 2010, 245 companies are registered in the activity division J61 Telecommunications, for 235 companies it was possible to calculate ETR according to the previously explained assumptions. Of these 235 companies, 121 companies had an ETR equal to 0.

\section{REFERENCES}

Arellano, M., and O. Bover. (1995). Another look at the instrumental variable estimation of error-components models. Journal of Econometrics 68: 29-51.

Blundell, R., and S. Bond. (1998). Initial conditions and moment restrictions in dynamic panel data models. Journal of Econometrics 87: 115-143.

Bubanić, M. (2020) Pregled performansi djelatnosti J61 Telekomunikacije u Republici Hrvatskoj. U: Skala, K. (ur.)MIPRO Proceedings 2020.

Bubanić, M., \& Korent, D. (2020). Efektivno opterećenje porezom na dobit u Hrvatskoj. Održivost javnih financija na putu u monetarnu uniju, 176-197.

Callihan, D. S. (1994). Corporate effective tax rates: A synthesis of the literature. Journal of Accounting Literature, 13, 1.

CBS (2020). Gross Domestic Product. Dostupno na https://www.dzs.hr/Hrv_Eng/Pokazatelji/MSI\%20 BRUTO\%20DOMACI\%20PROIZVOD.xlsx.

Dvorski, S., Kovšca, V., \& Vincek, Z. L. (2018). Ekonomija za poduzetnike: uvod u poslovnu ekonomiju. Varaždin: TIVA.

Feeny, S., Gillman, M., \& Harris, M. N. (2006). Econometric accounting of the Australian corporate tax rates: a firm panel example. Accounting Research Journal, 19, 64-73. 
Fernández-Rodríguez, E., \& Martínez-Arias, A. (2014). Determinants of the effective tax rate in the BRIC countries. Emerging Markets Finance and Trade, 50(sup3), 214-228.

FINA (2018). Baza podataka FINA-e. kupljeni podaci o poduzećima iz odabranih djelatnosti, Zagreb. FINA (2021). info.biz baza podatka FINa-e. Zagreb.

Gupta, S., \& Newberry, K. (1997). Determinants of the variability in corporate effective tax rates: Evidence from longitudinal data. Journal of accounting and public policy, 16(1), 1-34.

Kukić, N., (2007). Efektivno porezno opterećenje trgovačkih društava. Zagreb. Računovodstvo, revizija i financije, br.7/2007, pp. 98-102.

Lazăr, S. (2014). Determinants of the variability of corporate effective tax rates: Evidence from Romanian listed companies. Emerging Markets Finance and Trade, 50(sup4), 113-131.

Liu, X., \& Cao, S. (2007). Determinants of corporate effective tax rates: evidence from listed companies in China. Chinese economy, 40(6), 49-67.

Moreno-Rojas, J., González-Rodríguez, M. R., Martín-Samper, R. C., \& University of Seville. (2017). Determinants of the effective tax rate in the tourism sector: A dynamic panel data model. Tourism \& Management Studies, 13(3), 31-38. doi:10.18089/tms.2017.13304

Ooghe, E.; E. Schokkaert; and J. Flechet. 2003. The Incidence of Social Security Contributions: An Empirical Analysis. Empirica 30, no. 2: 81-106.

Ott, K. (Ed,), (1999). Porezni leksikon s višejezičnim rječnikom: engleski, hrvatski, francuski, njemački, španjolski, Institut za javne financije.

Richardson, G., \& Lanis, R. (2007). Determinants of the variability in corporate effective tax rates and tax reform: Evidence from australia. Journal of Accounting and Public Policy, 26(6), 689-704.

Rodriguez, E. F., \& Arias, A. M. (2012). Do business characteristics determine an effective tax rate. Chinese Economy, 45, 60-83.

Roodman, D. (2009). How to do xtabond2: An introduction to difference and system GMM in Stata. The stata journal, 9(1), 86-136.

Savitri, E. (2017). Determinants of effective Tax Rate of the top 45 Largest listed companies of Indonesia. International Journal of Management Excellence, 9(3), 1183-1188.

Siegfried, J. J. (1972). The relationship Between Economic Structure and the Effect of Political Influence: Empirical Evidence from the Corporation Income Tax Program. Ph.D. disertation. University of Wisconsin.

Spengel, C.; W. Li; K. Finke; and B. Zinn. 2011. The Computation and Comparison of the Effective Tax Burden in Four Asian Countries. Hitotsubashi Journal of Economics 52, no. 1: 13-39.

Šimović, H. (2009). Effective Corporate Income Tax Burden in Croatia. Zagreb International Review of Economics and Business, 12(2), 107-121.

Švaljek, S., (ed.) (2006). Efektivno porezno opterećenje trgovačkih društava u Republici Hrvatskoj. Zagreb: Ekonomski institut.

Vintilă, G., Gherghina, Ş. C., \& Păunescu, R. A. (2018). Study of effective corporate tax rate and its influential factors: Empirical evidence from emerging european markets. Emerging Markets Finance and Trade, 54(3), 571-590.

Wilkie, P.F. (1988). Corporate Average Effective Tax Rates and Inferences About Tax Preferences. Journal of the American Taxation Association 10, no. 1: 75-88.

Zimmerman, J. L. (1983). Taxes and firm size. Journal of Accounting and Economics, 5(1), 119-149. 